\title{
Formation of an Aluminide Coating on Hot Stamped Steel
}

\author{
Dong Wei FAN and Bruno C. De COOMAN \\ Graduate Institute of Ferrous Technology, Pohang University of Science and Technology, 790-784, Pohang, South Korea. \\ E-mail: decooman@postech.ac.kr
}

(Received on May 6, 2010; accepted on July 21, 2010)

\begin{abstract}
The degradation of type 1 aluminized coating during hot stamping leads to the coating cracking due to the formation of a brittle $\mathrm{FeAl}_{2}$ intermetallic phase. The formation of an aluminide coating prior to hot stamping was investigated as a method to simultaneously improve the coating ductility and achieve a good hot corrosion resistance of the hot stamped parts. A formable aluminide coating was obtained when the coating alloying was achieved during the pre-heating of the steel and an Fe content higher than 70 at\% (83 wt\%) was reached. The coating was identified as $\mathrm{Fe}_{3} \mathrm{Al}$ phase at room temperature. The formation of this aluminide coating on $22 \mathrm{MnB5}$ hot stamping steel was investigated in detail. The effect of this alternative hot stamping thermal cycle on the room temperature mechanical properties of the steel was also investigated.
\end{abstract}

KEY WORDS: aluminide; coating; hot stamping.

\section{Introduction}

Hot stamping is one of the most effective methods to produce ultra high strength steels (UHSS) for automotive bodies. Hot stamped steels are mainly used in the production of side impact beams, bumpers, B-pillars, roof rails, and tunnels. The use of hot stamped steel parts in body-inwhite construction can significantly increase the passenger safety, contribute to vehicle mass containment and reduce fuel consumption.

At present, the type 1 aluminized coating $(\mathrm{Al}-10 \mathrm{wt} \% \mathrm{Si}$ ) is used as a shield coating for the hot stamped steels. It protects steel from surface oxidation and decarburization, and enhances its corrosion resistance. Currently the 22MnB5 steel coated with $25-30 \mu \mathrm{m}$ thick type 1 aluminized coating is widely used. In the hot stamping process, the coated steel blank is heated in a furnace to a temperature in the range of $900-950^{\circ} \mathrm{C}$ for $3-10 \mathrm{~min}$. In the heating process, the steel becomes fully austenitic. The aluminized coating melts and reacts with the substrate steel to form solid intermetallic phases. After being transferred into press forming equipment, the steel blank is press formed in the temperature range of $600-800^{\circ} \mathrm{C}$ and simultaneously quenched by the water-cooled dies until the temperature reaches about $200^{\circ} \mathrm{C}$. During the deformation at high temperature, the coating is broken into segments which adhere to the steel substrate. The cracked coating deteriorates the surface appearance and exposes the steel to corrosion. ${ }^{1)}$ It is therefore necessary to explore possible solutions for the coating deterioration on hot stamped steels. These solutions should lead to a steel surface with a high temperature oxidation resistance and an adequate formability without cracking.

Aluminide coatings are commonly used as thermal barrier coatings on work pieces for elevated temperature service. Two methods are used to form iron aluminide coatings.
In the calorizing process, the work piece is covered with a $\mathrm{Fe}-\mathrm{Al}$ alloy powder, sintered alumina and $\mathrm{NH}_{4} \mathrm{Cl}$. The $\mathrm{NH}_{4} \mathrm{Cl}$ acts as a halide activator which transports the $\mathrm{Al}$ in gaseous form to substrate. The work piece is then heated at $850-1000^{\circ} \mathrm{C}$ for several hours. A Fe-Al solid solution or an intermetallic compound is formed at the surface. ${ }^{2)}$ In the second process, the steel is coated with metallic $\mathrm{Al}$ or an $\mathrm{Al}$ alloy by hot dip aluminizing. During heating at 700-1 100 ${ }^{\circ} \mathrm{C}$, the substrate steel diffuses into the coating and iron aluminide phases are formed. ${ }^{2,3)}$

In previous work, ${ }^{3-5)}$ iron aluminide coatings were produced by heat treating aluminized steels. The ductile FeAl or $\mathrm{Fe}_{3} \mathrm{Al}$ phase was found to be preferred as a shield coating instead of the brittle $\mathrm{FeAl}_{2}$ or $\mathrm{Fe}_{2} \mathrm{Al}_{5}$ phase. The formability of the iron aluminide coating was not an issue in those studies, because the coated parts did not need to be deformed subsequently. In the hot stamping process, the steel blanks are plastically deformed at high temperature, and the formability of the coating is an essential aspect of the process.

\section{Experimental Procedure}

The material used in the present study was a $22 \mathrm{MnB} 5$ steel sheet, which was hot dip coated on both side with a type 1 aluminized coating ( $\mathrm{Al}-10 \mathrm{wt} \% \mathrm{Si})$. The steel composition had $0.22 \mathrm{wt} \% \mathrm{C}, 1.2 \mathrm{wt} \% \mathrm{Mn}$ and $20 \mathrm{ppm} \mathrm{B}$ as main alloying elements. Two coating thicknesses were used: 25 $\mu \mathrm{m}$ and $10 \mu \mathrm{m}$.

In the present work, the coated steel sheet was heated in a box furnace in the $930-1050^{\circ} \mathrm{C}$ temperature range with an air atmosphere to simulate the heat treatment of hot stamping. The steel was also tested on a Gleeble 3500 thermo-mechanical tester to simulate the hot deformation during the hot stamping process. The specimens were de- 
formed to $30 \%$ engineering strain with a strain rate of $0.5 / \mathrm{s}$ in the temperature range of $600-800^{\circ} \mathrm{C}$. The coating cross sections were polished with diamond suspension down to $1 \mu \mathrm{m}$. The specimens were observed in a Zeiss Ultra55 Field Emission Scanning Electron Microscopy (FE-SEM) operated at $20 \mathrm{kV}$ and analyzed by Energy Dispersive Spectroscopy (EDS). The fracture surface of cracked coating was also analyzed. Specimens were prepared using Focused Ion Beam (FIB) method and observed in a JEOL 2100F Transmission Electron Microcopy (TEM) operated at $200 \mathrm{keV}$. The Vickers hardness of the steel was measured with a load of $0.5 \mathrm{~kg}$ and a dwell time of $10 \mathrm{~s}$. The specimens were polished, etched with 2 vol\% Nital and observed in the FE-SEM. The prior austenite grain size was measured by using intercept method according to ASTM standard E112.

\section{Results and Discussion}

\subsection{Coating Degradation in Conventional Hot Stamp- ing Process}

In the hot stamping process, some parts of the steel, such as those in the corner areas of the hot stamped parts, are severely deformed at $600-800^{\circ} \mathrm{C}$. $22 \mathrm{MnB} 5$ steel sheet coated with type 1 aluminized coating was thermo-mechanically tested in a Gleeble 3500 to simulate the hot stamping process. In the present study, the specimens were heated at $930^{\circ} \mathrm{C}$ for $5 \mathrm{~min}$, and then cooled to $800^{\circ} \mathrm{C}$ with a cooling rate of $20^{\circ} \mathrm{C} / \mathrm{s}$. The specimen was then isothermally deformed uniaxially to $30 \%$ engineering strain at $800^{\circ} \mathrm{C}$.

During the deformation at $800^{\circ} \mathrm{C}$, the coating broke into segments, which remained adherent to the steel substrate. This is shown in Fig. 1(a). Bare steel was exposed between the broken coating segments. The lengths of coating segments and gaps between the segments were found to be shorter when the strain rate increased. The coating fracture pattern of the coating became finer at higher strain rates (Fig. 1(b)). The cracking of the coating caused by plastic deformation was reported previously by Denner et al. for a type 1 aluminized coating heat treated at $\left.816^{\circ} \mathrm{C} .{ }^{6}\right)$
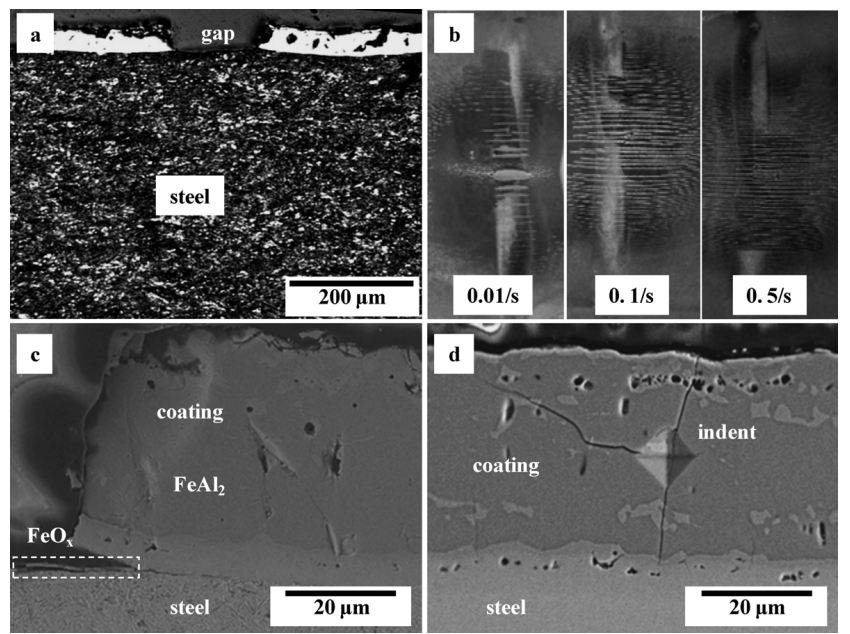

Fig. 1. (a) The cross section and (b) the surface of the cracked coating on $22 \mathrm{MnB} 5$ steel. (c) The FE-SEM micrograph of coating segment in edge and (d) FE-SEM micrograph of the cracked coating cross section after hardness indentation at room temperature.
The cracked coating was identified as a layer of $\mathrm{FeAl}_{2}$ intermetallic phase (Fig. 1(c)). A thin layer of thermal oxide, approximately $1 \mu \mathrm{m}$ thick, was present between the coating and steel substrate. A small gap can be observed between this layer and substrate steel, which implies that this layer might easily peel off. The EDS analysis revealed that this layer was $\mathrm{FeO}_{x}$. These exposed areas are expected to be much more susceptible to corrosion compared with the areas still covered by the intermetallic layer.

Figure 1(d) shows the coating cross section of the $0 \%$ strained sample after heat treatment. Its thickness is same as the $30 \%$ strained one in Fig. 1(c), which implies that the coating did not plastically deform during the hot deformation.

A hardness indent with a load of $0.1 \mathrm{~kg}$ was made in the coating and observed in the FE-SEM (Fig. 1(d)). It can be clearly seen that cracks were formed in the indent area and propagated in a brittle fashion into the coating. This implies that the $\mathrm{FeAl}_{2}$ coating is brittle both during hot forming and at room temperature. Hence the coating can easily be damaged during service.

From the above, it is clear that, during conventional hot stamping type 1 aluminized coating reacts with the steel substrate to form the $\mathrm{FeAl}_{2}$ intermetallic phase, which is brittle both at high temperature and at room temperature. In addition, the cracked coating deteriorates the surface appearance and makes the exposed segments of steel susceptible to corrosion. The coating is also susceptible to cracking during service. It is therefore necessary to explore alternative heat treatments for Al-Si coated hot stamped steels, so that the coating may provide a high temperature oxidation resistance and display an adequate formability during hot stamping.

\subsection{Criteria for Coating Ductility}

An aluminized steel specimen was heated for $4 \mathrm{~min}$ at $1050^{\circ} \mathrm{C}$ and deformed uniaxially $30 \%$ at $800^{\circ} \mathrm{C}$ at a strain rate of $0.5 / \mathrm{s}$. It was found that the coating cracked during the hot deformation. In Fig. 2(a) the fracture surface of a coating crack is shown. The top surface of the coating consisted of an oxide layer. The region beneath the coating was the steel surface which was oxidized when the crack formed at high temperature. It can be clearly seen that the coating consisted of two distinct layers, each with a characteristic fracture morphology. The upper part of the coating crack surface was facetted due to brittle fracture, and it is labeled as region 1 . The lower half of the coating crack surface had a ductile fracture appearance, and it is labeled as region 2 . It is very likely that region 1 cracked initially dur-
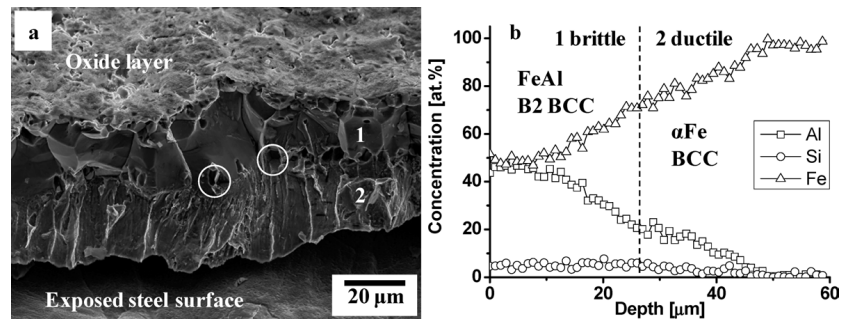

Fig. 2. (a) The fracture surface of the cracked coating, (b) the cross sectional composition profile of the coating obtained by EDS. 
ing plastic deformation and that the crack propagated into the region 2 causing the final failure of the entire coating. If the entire coating had been composed of region 2 , it is expected that the coating would have been able to deform plastically with the substrate steel without cracking.

Between region 1 and 2, there are some voids, which are indicated with circles in Fig. 2(a). These voids are very likely Kirkendall voids formed due to the different diffusivities of $\mathrm{Fe}$ or $\mathrm{Al}$ in regions 1 and 2. In the composition profile shown in Fig. 2(b), the regions 1 and 2 are separated by a dashed line. Region 1 had a Fe content in the range of $50-70$ at $\%$. Region 2 had a Fe content in the range of 70-98 at \%. The Si content was about 5 at $\%$. In the present study, Si was considered to have same behavior in the coating as $\mathrm{Al}$, and the coating was treated as a binary $\mathrm{Fe}-\mathrm{Al}$ system. This is reasonable as $\mathrm{Si}$ has an atomic radius and molecular weight very similar to that of $\mathrm{Al}$, and it is also a strong ferrite stabilizing element.

The alloyed coating covered the range of 50 to $98 \mathrm{at} \% \mathrm{Fe}$ after heating at $1050^{\circ} \mathrm{C}$ for $4 \mathrm{~min}$. The $\mathrm{Fe}-\mathrm{Al}$ binary phase diagram is shown in Fig. 3(a). ${ }^{7)}$ The transition between ordered B2 FeAl phase and the disordered $\alpha$-Fe phase with $\mathrm{Al}$ in solid solution occurs at $1050^{\circ} \mathrm{C}$ for an $\mathrm{Fe}-\mathrm{Al}$ alloy

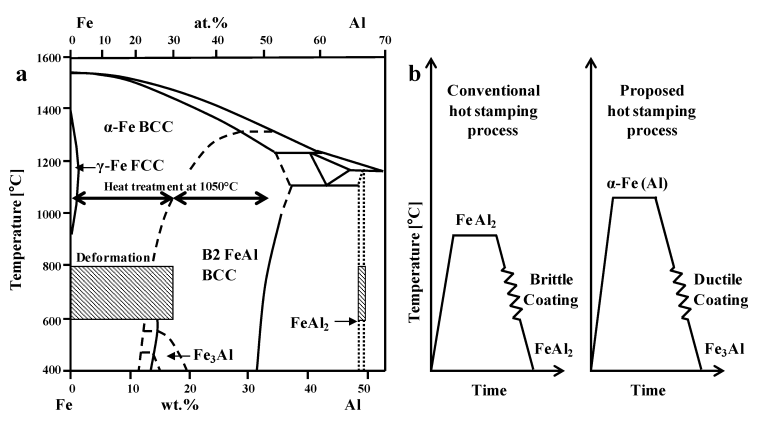

Fig. 3. (a) The Fe-Al binary phase diagram (reproduced from Ref. 7)) and (b) comparison between conventional hot stamping process and proposed alternative hot stamping process. with 70 at $\%$ Fe. This is the same as the composition of the interface between regions 1 and 2 in Fig. 2(b). From Fig. 3 (a) it can be estimated that region 1 was very likely the ordered B2 FeAl phase. Region 2 was disordered $\alpha$-Fe with $\mathrm{Al}$ in solid solution at high temperature. According to the $\mathrm{Fe}-\mathrm{Al}$ phase diagram this phase transforms to the ordered $\mathrm{D} 03 \mathrm{Fe}_{3} \mathrm{Al}$ phase at low temperatures.

Regions 1 and 2 were observed and analyzed at high resolution by TEM. Figures 4(a) and 4(b) are the $\langle 110\rangle$ lattice image and the corresponding diffraction pattern of region 1 , which was identified as the ordered B2 FeAl phase. The inter-planar distances $d_{002}$ and $d_{110}$ were measured to be $0.144 \mathrm{~nm}$ and $0.206 \mathrm{~nm}$, respectively. The calculated lattice parameter was $0.290 \mathrm{~nm}$. Figures $4(\mathrm{~d})$ and $4(\mathrm{e})$ are the $\langle 110\rangle$ lattice image and diffraction pattern of region 2 , which was identified as ordered D03 $\mathrm{Fe}_{3} \mathrm{Al}$ phase. The inter-planar distances $d_{004}$ and $d_{220}$ were measured as $0.145 \mathrm{~nm}$ and $0.209 \mathrm{~nm}$ respectively. The calculated lattice parameter was $0.585 \mathrm{~nm}$. These measured values are in agreement with the reported lattice parameter values of $0.291 \mathrm{~nm}$ for $\mathrm{FeAl}$ and $0.579 \mathrm{~nm}$ for $\mathrm{Fe}_{3} \mathrm{Al}$, respectively. ${ }^{8)}$ The diffraction patterns of regions 1 and 2 are shown in Fig. 4(b) and 4(e). They are the characteristic diffraction patterns for the $\mathrm{B} 2 \mathrm{FeAl}$ and $\mathrm{D} 03 \mathrm{Fe}_{3} \mathrm{Al}$ phases with $\langle 110\rangle$ zone axis.

The diffraction spots in italics are forbidden in the disordered bcc phase, but they are allowed superlattice reflections in the ordered $\mathrm{B} 2 \mathrm{FeAl}$ and $\mathrm{D} 03 \mathrm{Fe}_{3} \mathrm{Al}$ phases (Figs. 4(c) and 4(f)). For example the (1111) diffraction spot in Fig. 4(b) is caused by the Al atoms which occupy the central position in the B2 unit cell (Fig. 4(c)). The (11̄i) diffraction spot in Fig. 4(e) is caused by the $\mathrm{Al}$ atoms which form a central tetrahedral unit in the D03 unit cell (Fig. 4(f)).

From the above analysis, it is clear that there are two criteria to obtain a formable coating: the $\mathrm{Fe}$ content in the coating should be above $70 \mathrm{at} \%(83 \mathrm{wt} \%)$ at $1050^{\circ} \mathrm{C}$. And the coating should have a disordered bec structure at high temperature and an ordered $\mathrm{Fe}_{3} \mathrm{Al} \mathrm{D} 03$ structure at low tem-
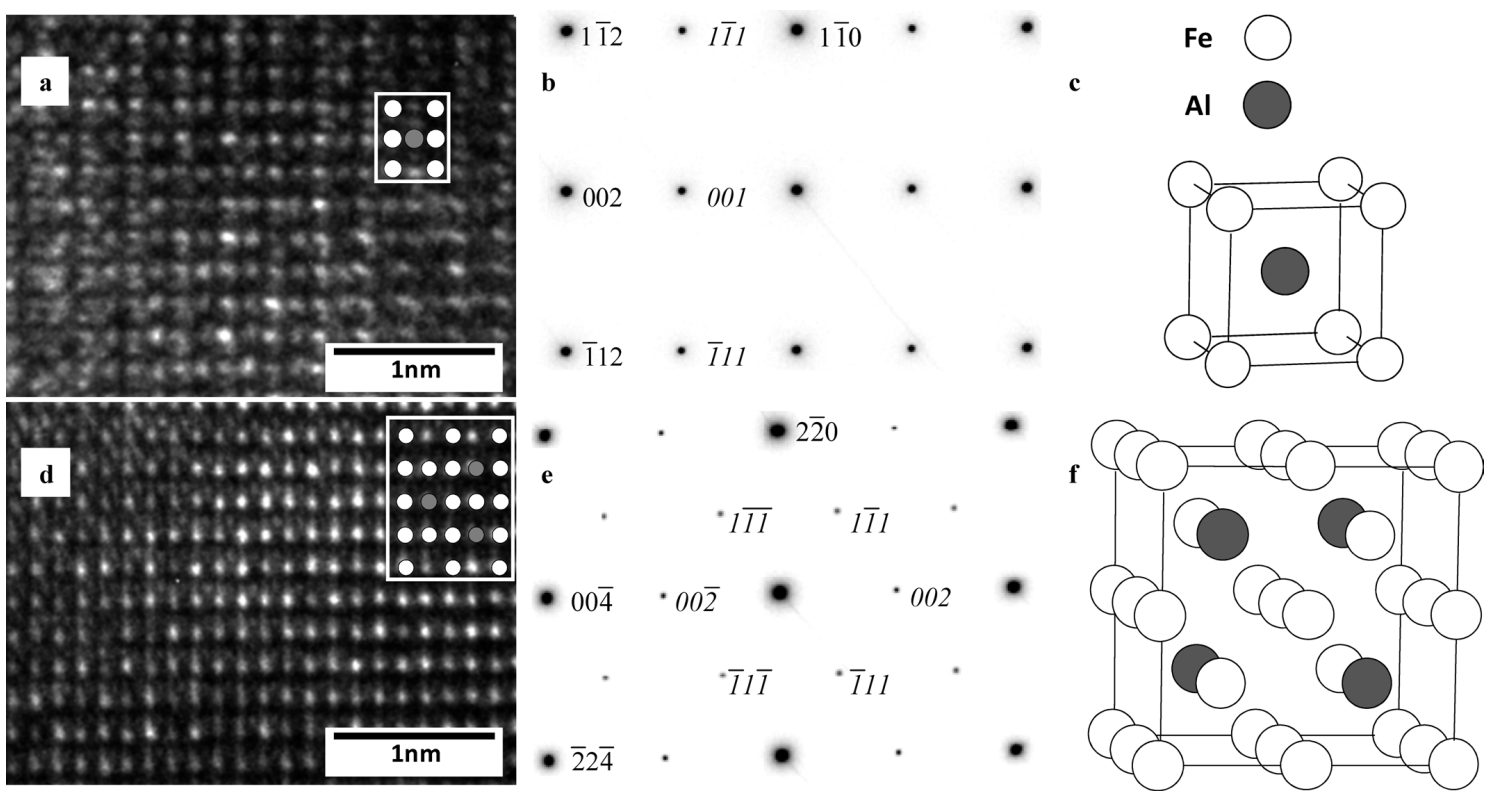

Fig. 4. (a) Lattice image, (b) corresponding diffraction pattern and (c) crystallographic structure for the ordered B2 FeAl phase in region 1 . (d) Lattice image, (e) corresponding diffraction pattern and (f) crystallographic structure for the order D03 Fe ${ }_{3} \mathrm{Al}$ phase in region 2 . The zone axis is $\langle 110\rangle$ in both cases. The inserts in (a) and (b) are the corresponding unit cells. 
perature. This $\mathrm{Fe}_{3} \mathrm{Al}$ aluminide coating is desired for the hot stamping process and it can be easily be obtained by using an adapted pre-heating process.

In the hot stamping process, the steel sheets are usually deformed in the temperature range of $600-800^{\circ} \mathrm{C}$. In the present study, the samples were pre-heated at $1050^{\circ} \mathrm{C}$ and deformed at $800^{\circ} \mathrm{C}$. On the basis of the equilibrium $\mathrm{Fe}-\mathrm{Al}$ binary phase diagram (Fig. 3(a)), it is expected that from 1050 to $800^{\circ} \mathrm{C}$, the disordered bcc $\alpha$-Fe phase should partially transform to $\mathrm{B} 2 \mathrm{FeAl}$. The $\alpha-\mathrm{Fe} / \mathrm{FeAl}$ phase boundary is approximately 76 at $\%(87 \mathrm{wt} \%)$ Fe at $800^{\circ} \mathrm{C}$. This transformation was however not observed in the present study. This implies that the disordered $\alpha$-Fe phase remained present in the undercooled state at $800^{\circ} \mathrm{C}$. A cooling rate of $20^{\circ} \mathrm{C} / \mathrm{s}$ therefore effectively suppresses the transformation of the disordered $\alpha$-Fe phase to the ordered FeAl phase.

It has been reported that the FeAl phase, alloyed with $\mathrm{Cr}$, $\mathrm{Ti}, \mathrm{Zr}$, or $\mathrm{B}$, was ductile in tensile and compressive deformation at temperature above $700^{\circ} \mathrm{C},{ }^{9,10)}$ and that it could be super plastic at high temperature when tested at low strain rates even for a large grain size microstructure. ${ }^{11)}$ Baker et al. mentioned that a $\mathrm{Fe}-40 \mathrm{at} \% \mathrm{Al}$ alloy had no elongation and a transgranular cleavage fracture surface when deformed in the temperature range of $950-1100^{\circ} \mathrm{C}$ at relatively high strain rates. The ductile to brittle transition showed a clear dependence on the Al content and the deformation temperature. ${ }^{12)}$ In the present study the $\mathrm{FeAl}$ phase was found to be brittle when tested at strain rate of $0.5 / \mathrm{s}$ in the temperature range of $600-800^{\circ} \mathrm{C}$. In this case the $\mathrm{FeAl}$ phase contained 5 at $\% \mathrm{Si}$. It is presently unknown if this $\mathrm{Si}$ content may cause the FeAl to be brittle. This phenomenon needs further investigation.

\subsection{Formation of a Ductile Coating for Hot Stamping}

From the previous paragraphs, it is clear that the disordered bec $\alpha$-Fe phase with $\mathrm{Al}$ in solid solution is the desired coating during the hot stamping process. In order to make the initial Al-Si coating transform to a disordered bcc $\alpha$-Fe phase, the Fe content in the coating must be higher than the threshold value of 70 at $\%$ at $1050{ }^{\circ} \mathrm{C}$. Two methods can be considered to increase the Fe content in the surface layer.

First, a steel coated with a thick type 1 aluminized coating needs to be heated for a longer time or at a higher temperature. This process will increase the diffusion time or the diffusivity of $\mathrm{Fe}$ in order to increase its content in the coating. The other method is to reduce the coating thickness i.e. the diffusion distance, so that the Fe content can reach 70 at $\%$ in a shorter time or at a lower temperature. In the present study, specimens coated with $25 \mu \mathrm{m}$ and $10 \mu \mathrm{m}$ type 1 aluminized coating were tested at a temperature of $1050^{\circ} \mathrm{C}$ for different time. The thermal cycles are shown schematically in Fig. 3(b). After the heat treatment, cross sections of the samples were observed in the FE-SEM. Their composition profiles are shown in Fig. 5.

For the specimen coated with a $25 \mu \mathrm{m}$ thick coating, the coating thickness increased to about $93 \mu \mathrm{m}$ after heating at $1050^{\circ} \mathrm{C}$ for $30 \mathrm{~min}$ (Fig. 5(a)). The Fe content in the coating was slightly more than $70 \mathrm{at} \%$. For the sample with a $10 \mu \mathrm{m}$ thick coating, the coating thickness increased to about $30 \mu \mathrm{m}$ after heating at $1050^{\circ} \mathrm{C}$ for only $4 \mathrm{~min}$ (Fig. $5(\mathrm{~b})$ ). The Fe content in the coating was also higher than 70 at $\%$ in this case.

Figure 6 shows the cross-sectional images of the $25 \mu \mathrm{m}$ coated specimens. In Fig. 6(a) the initial coating consisted of an Al matrix layer in which eutectic Si was formed. An intermetallic layer was present at the steel/coating interface, which was identified as the $\mathrm{Fe}_{2} \mathrm{SiAl}_{7}$ phase by EDS. After a heat treatment at $1050^{\circ} \mathrm{C}$ for $30 \mathrm{~min}$, the $\mathrm{Fe}$ diffused into the coating and its content at the coating surface increased to $70 \mathrm{at} \%$. The thickness of the coating increased to $93 \mu \mathrm{m}$. The Kirkendall voids coalesced and formed a more or less continuous cavity, which retarded the Fe diffusion into the upper side of the coating (Fig. 6(b)). This phenomenon very likely resulted in a longer time to increase the Fe content in the entire coating. During deformation the voids were extended and formed larger gaps in the coating (Fig. 6(c)). The thickness of the coating was reduced to $75 \mu \mathrm{m}$ due to plastic deformation. No delamination or powdering of the coating was observed during deformation. And the coating remained strongly adherent to the substrate steel.

The formation of an aluminide coating from a thick aluminized coating by diffusion treatment has already been reported in literatures. In the work of Kobayashi et al., ${ }^{3)}$ a $60 \mu \mathrm{m}$ thick pure aluminum coating was reported to have transformed to a $100 \mu \mathrm{m}$ thick $\mathrm{Fe}_{3} \mathrm{Al}$ coating after heating at $1100^{\circ} \mathrm{C}$ for $1 \mathrm{~h}$. The existence of $\mathrm{FeAl}_{2}$ phase was ob-
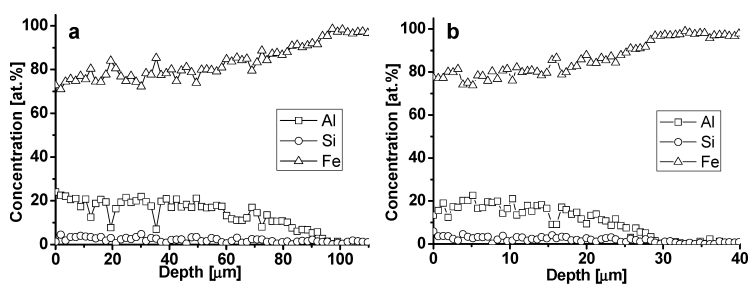

Fig. 5. The compositional depth profiles of (a) a $25 \mu \mathrm{m}$ coated specimen after $30 \mathrm{~min}$ at $1050^{\circ} \mathrm{C}$ and (b) a $10 \mu \mathrm{m}$ coated specimen after $4 \mathrm{~min}$ at $1050^{\circ} \mathrm{C}$.
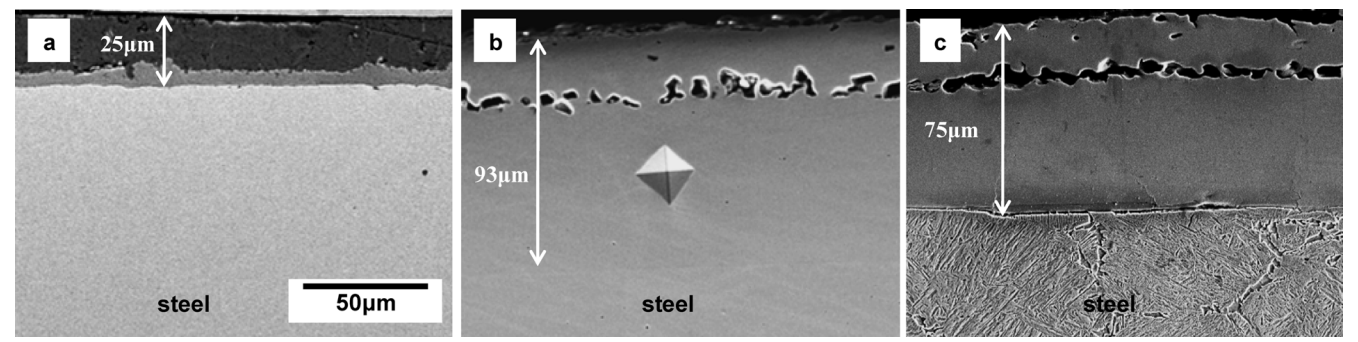

Fig. 6. FE-SEM micrographs of the cross section of the $22 \mathrm{MnB} 5$ steel coated with thick Al-10wt $\%$ Si coating (a) as hot dipped, (b) heat treated at $1050^{\circ} \mathrm{C}$ for $30 \mathrm{~min}$ and (c) heat treated at $1050^{\circ} \mathrm{C}$ for $30 \mathrm{~min}$ and $30 \%$ strained at $700^{\circ} \mathrm{C}$. 

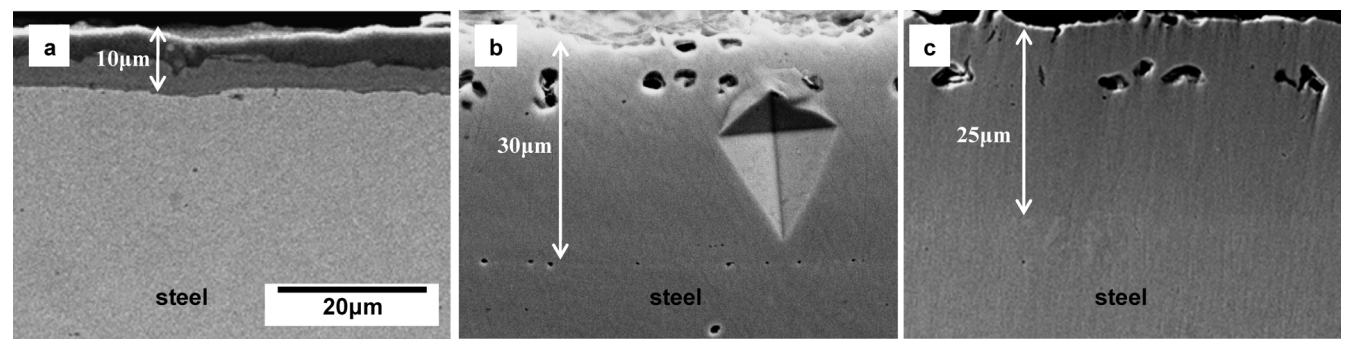

Fig. 7. FE-SEM micrographs of the cross section of the $22 \mathrm{MnB} 5$ steel coated with thin $\mathrm{Al}-10 \mathrm{wt} \% \mathrm{Si}$ coating (a) as hot dipped, (b) heat treated at $1050^{\circ} \mathrm{C}$ for $4 \mathrm{~min}$ and (c) heat treated at $1050^{\circ} \mathrm{C}$ for $4 \mathrm{~min}$ and $30 \%$ strained at $700^{\circ} \mathrm{C}$.

served in the final coating. In the work of Chang et al., ${ }^{4)} \mathrm{a}$ $25 \mu \mathrm{m} \mathrm{Al}-7 \mathrm{wt} \% \mathrm{Si}$ coating was heat treated at $850^{\circ} \mathrm{C}$ for $24 \mathrm{~h}$. The final thickness was almost $90 \mu \mathrm{m}$. FeAl, $\mathrm{FeAl}_{2}$, and $\mathrm{Fe}_{2} \mathrm{Al}_{5}$ were found to be present in the final room temperature alloy coating. The formation of voids was also reported. The formability of the diffusion treated coating was however not discussed in these previous reports.

Figure 7 shows the cross sections of the $10 \mu \mathrm{m}$ coated specimens. The original thin coating structure was similar to that of the $25 \mu \mathrm{m}$ coating (Fig. 7(a)). After heat treating at $1050{ }^{\circ} \mathrm{C}$ for $4 \mathrm{~min}$, the $\mathrm{Fe}$ content at coating surface increased to $70 \mathrm{at} \%$. The thickness of the coating increased to $30 \mu \mathrm{m}$. Due to the shorter duration of the thermal cycle, the number and the size of voids were much smaller than in the case of thicker coating, and they had a less retarding effect on the Fe diffusion into the topmost layer (Fig. 7(b)). During deformation the voids were extended and became larger (Fig. 7(c)). The coating thickness was reduced to $25 \mu \mathrm{m}$.

The tests shown that, both the $25 \mu \mathrm{m}$ and $10 \mu \mathrm{m}$ coatings alloyed to form a disordered bcc phase, were formable and did not crack or delaminate during deformation tests. Considering the distribution of voids in the coating and the efficiency of the process, the $10 \mu \mathrm{m}$ thin coating heated at $1050^{\circ} \mathrm{C}$ for $4 \mathrm{~min}$ is preferred. It is estimated that the heating time or temperature can be reduced further if the initial coating thickness is decreased.

As the coating thickness varied and the coating/steel interface was unclear after alloying, it was difficult to precisely measure the coating thickness. Nevertheless the coating thickness strain could be evaluated, and compared to the thickness strain of the substrate steel. The thickness of substrate steel decreased from 1.65 to $1.41 \mathrm{~mm}$ after $30 \%$ tensile deformation. The thickness strain was about 0.15 . The thicknesses of the thick coating before and after deformation were $93 \mu \mathrm{m}$ and $75 \mu \mathrm{m}$. This corresponds to a strain of about 0.19 . The thicknesses of the thin coating before and after deformation were $30 \mu \mathrm{m}$ and $25 \mu \mathrm{m}$. This corresponds to a strain of about 0.17 . These similar thickness strains imply that the coatings were completely plastically deformed together with the substrate steel.

The coating layer hardness after a conventional thermal cycle and the new thermal cycle are compared in Fig. 8. The hardness of the layer was 769 after the conventional cycle. In contrast, the hardness of the $25 \mu \mathrm{m}$ thick coating obtained after heating at $1050^{\circ} \mathrm{C}$ for $30 \mathrm{~min}$ was only 311 . The hardness of the $10 \mu \mathrm{m}$ coating obtained after heating at $1050^{\circ} \mathrm{C}$ for $4 \mathrm{~min}$ was also low, i.e. 222. As shown in Fig. $1(\mathrm{~d})$, the hardness test also resulted in the formation of brittle cracks in the layer formed during the conventional HPF

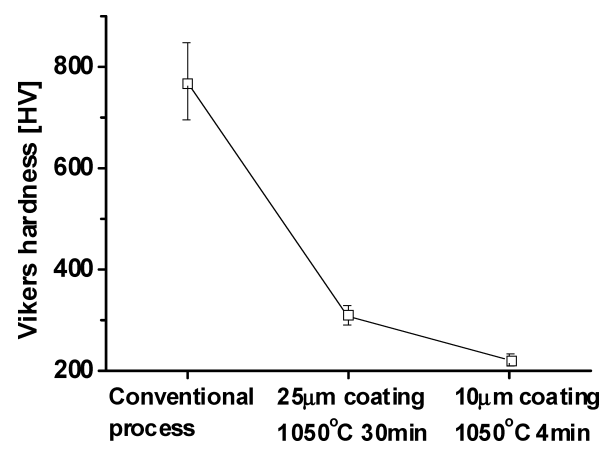

Fig. 8. The hardness comparison of coating obtained in conventional process and the ductile coatings formed in the new thermal cycles.

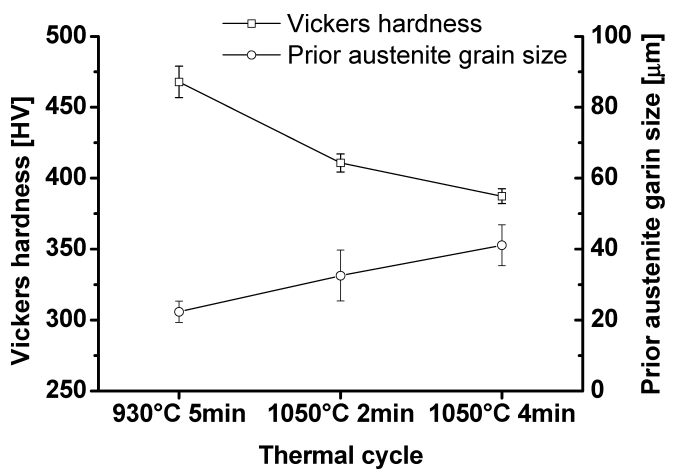

Fig. 9. Comparison of hardness and prior austenite grain size of $22 \mathrm{MnB} 5$ steel after different thermal cycles.

process. The cracks caused variations in the measured indent size. This is the reason for the larger error bars associated with the hardness data for the conventionally processed coating. Figures 6(b) and 7(b) show the hardness indents in the $25 \mu \mathrm{m}$ coating heated $30 \mathrm{~min}$ to $1050^{\circ} \mathrm{C}$ and the $10 \mu \mathrm{m}$ coating after heating $4 \mathrm{~min}$ at $1050^{\circ} \mathrm{C}$, respectively. No cracks were observed in both cases. The indent in Fig. 7(b) showed a pronounced asymmetry in the coating thickness direction, which implied that the hardness decreased in the direction from the surface to the bulk. This is due to the hardness gradually decreasing with increasing Fe content towards the steel substrate. From the hardness measurement and indents morphology, it is clear that the coatings formed during the new thermal cycle were ductile both at high temperature and at room temperature.

\subsection{The Influence of the Thermal Cycle on the Me- chanical Properties}

The hardness of $22 \mathrm{MnB} 5$ steel after heating at $1050^{\circ} \mathrm{C}$ was shown in Fig. 9 and compared with the hardness of the 
steel after heat treatment in the conventional HPF thermal cycle. All the specimens had a martensitic microstructure. Compared with the steel produced in a conventional hot stamping process $\left(930^{\circ} \mathrm{C}, 5 \mathrm{~min}\right)$, the steel hardness decreased slightly after heating at $1050^{\circ} \mathrm{C}$ for $4 \mathrm{~min}$. The high heating temperature resulted in coarsening of the prior austenite grain size and this, in turn, lead to coarsening of packet size in the quenched martensite. As a consequence, the hardness of martensite decreased. This implies that the heating time at $1050^{\circ} \mathrm{C}$ should be kept to a minimum and that thin coatings are preferred. The influence of the new thermal cycle on the steel mechanical properties at room temperature should also be taken into account when the hot stamped parts are designed.

\section{Conclusion}

It was found that the ordered $\mathrm{B} 2 \mathrm{FeAl}$ phase was brittle and that the disordered $\alpha$-Fe phase with Al in solid solution was ductile during high temperature deformation. The two criteria for obtaining a formable coating on a hot stamped steel is that the Fe content in the coating should be above 70 at $\%$ and that the disordered $\alpha$-Fe phase with $\mathrm{Al}$ in solid solution should be formed. This high temperature disordered $\alpha$-Fe phase transforms to the ordered D03 $\mathrm{Fe}_{3} \mathrm{Al}$ phase during cooling to room temperature.

A $10 \mu \mathrm{m}$ aluminized $22 \mathrm{MnB} 5$ steel can be used to form this aluminide coating after heating at $1050^{\circ} \mathrm{C}$ for only $4 \mathrm{~min}$. The coating has a good formability at high temperature. Compared to the conventional hot stamping method, the use of a thinner coating and a higher heating temperature make it possible to avoid the formation of cracks dur- ing the hot stamping process. This ordered D03 $\mathrm{Fe}_{3} \mathrm{Al}$ aluminide layer is ductile at room temperature as well.

The decreased steel strength caused by higher temperature pre-heating should however also be considered when hot stamped parts are designed.

\section{Acknowledgement}

The authors gratefully acknowledge the POSCO Technical Research Laboratories for providing the materials. POSCO C\&C is also acknowledged for providing the access to the aluminizing coating simulator.

\section{REFERENCES}

1) D. W. Fan, H. S. Kim and B. C. De Cooman: Steel Res. Int., 80 (2009), 241.

2) A. Bahadur and O. N. Mohanty: Mater. Trans. JIM, 36 (1995), 1170.

3) S. Kobayashi and T. Yakou: Mater. Sci. Eng. A, 338 (2002), 44.

4) Y. Y. Chang, C. C. Tsaur and J. C. Rock: Surf. Coat. Technol., 200 (2006), 6588.

5) X. Luo, K. Chen and Y. Wang: Proc. of 1st Congress of Int. Surface Engineering, ASM Int., Ohio, (2003), 296.

6) S. Denner and Y.-W. Kim: Proc. of 112th AIME Annual Meeting, Metallurgical Society of AIME, Atlanta, Georgia, (1983), 233.

7) ASM Handbook, Vol. 3, ASM International, Materials Park, Ohio, (1999), 2.44

8) P. Villars, L. D. Calvert and W. B. Pearson: Pearson's Handbook of Crystallographic Data for Intermetallic Phases, American Society for Metals, Metals Park, Ohio, (1985), 972.

9) D. H. Sastry, Y. V. R. K. Prasad and S. C. Deevi: Mater. Sci. Eng. A, 299 (2001), 157.

10) M. Kupka and M. Prewendowski: J. Alloys Compd., 437 (2007), 367.

11) D. Li, A. Shan, Y. Liu and D. Lin: Scr. Metall. Mater, 33 (1995), 681.

12) I. Baker and P. R. Munroe: Int. Mater. Rev., 42 (1997), 181. 